\title{
Organic control of Bemisia tabaci Genn. on Capsicum annuum with entomopathogenic fungi raw secondary metabolites
}

\author{
LOEKAS SOESANTO`, BISIRIL FATIHAH, ABDUL MANAN, ENDANG MUGIASTUTI, \\ NUR PRIHATININGSIH \\ Faculty of Agriculture, Universitas Jenderal Soedirman. Jl. Dr. Suparno No. 63, Purwokerto Utara, Banyumas 53123, Central Java, Indonesia. \\ Tel.: +62-281-638791, `email: lukassusanto26@gmail.com
}

Manuscript received: 22 October 2020. Revision accepted: 25 November 2020.

\begin{abstract}
Soesanto L, Fatihah B, Manan A, Mugiastuti E, Prihaningsih N. 2020. Organic control of Bemisia tabaci Genn. on Capsicum annuum with entomopathogenic fungi raw secondary metabolites. Biodiversitas 21: 5786-5791. Control of whitefly with entomopathogenic fungi raw secondary metabolites and their correlation was investigated under control condition. The in vitro test u sed randomized completely design consisted of five treatments (raw secondary metabolites of Beauveria bassiana B16 and B10, Metarhizium anisopliae M16, Lecanicillium lecanii L16, and no treatments) and repeated five times. The in planta one used Latin square design consisted of five treatments and repeated five times. Variables observed were the mortality of whitefly imago, chiti nolytic index, incubation period, viral disease intensity, plant height and total leaves per plant. The results showed that all treatment of raw secondary metabolites of entomopathogenic fungi caused mortality in the B. tabaci imago by $77.8 \%$ (B. bassiana B16); 71.5\% (B. bassiana B10); $66.7 \%$ (M. anisopliae M16); and 59.5\% (L. lecanii L16). All raw secondary metabolites of entomopathogenic fungi reduce the intensity of viral diseases by 79.98\% (B. bassiana B16); 74.00\% (B. bassiana B10); 72.23\% (L. lecanii L16); and 55.41\% (M. anisopliae M16). The correlation between $B$. tabaci mortality due to raw secondary metabolites of entomopathogenic fungi with the viral disease intensity is very close and opposite. Every $1 \%$ increase in pest mortality causes decrease in viral intensity by $1.346 \%$.
\end{abstract}

Keywords: Bemisia tabaci, entomopathogenic fungi, raw secondary metabolites, chitinase extracellular, viral disease

\section{INTRODUCTION}

Chili is an important commodity supporting the food sector and industry. Supriadi et al. (2018) explain that in Indonesia about $80 \%$ of chili production is allocated for household food needs, the remaining $20 \%$ is absorbed by the industrial sector. There are two types of chili plants that are generally cultivated in Indonesia, namely large red chili $(C$. anпиит L.) and cayenne pepper $(C$. frutescens $\mathrm{L}$.). Production constraints due to pests and diseases in the field still occur. Whitefly (B. tabaci; Hemiptera: Aleyrodidae) is a pest as well as a vector that causes viral diseases in large red chili commodities (Navas-Castillo et al. 2011; MorenoDelafuente et al. 2013).

Virus control is currently emphasized on pest control which acts as a vector. According to He et al. (2013) and Rodríguez et al. (2019), periodic application of pesticides is carried out on $B$. tabaci to prevent further spread of the virus. The control of whitefly $B$. tabaci using chemical pesticides with the dosage and intensity of application has exceeded reasonable limits causing the danger of pest resistance (Legg et al. 2014). According to De Barro et al. (2011) and Macfadyen et al. (2018), B. tabaci has developed into many biotypes. Chemical pesticides to control whitefly must slowly turn to effective control. Expected control does not cause resistance to $B$. tabaci pests. The alternative is to utilize the role of entomopathogenic fungi. Mascarin et al. (2013) and AbdelRaheem and Al-Keridis (2017) supported that entomopathogenic fungi as biological control agents have the potential to control pests, replacing synthetic insecticides. In its application in the field entomopathogenic fungi have weaknesses such as abiotic stress factors, such as temperature, humidity and sunlight (Mustafa and Kaur 2008; Liu and Lin 2013; Han et al. 2014), the stability of conidia and blastopora production (Fernandes et al. 2012; Oliveira et al. 2018), and insect cuticle as a barrier for all entomopathogenic fungi to penetrate directly (Keyhani 2018).

Furthermore, the role of entomopathogenic fungi can be enhanced with the help of their raw secondary metabolites produces. The raw secondary metabolism of entomopathogenic fungi plays a role in increasing control effectiveness. According to Kim et al. (2013), entomopathogenic fungi bred in the filtrate (potato dextrose broth) can produce raw secondary metabolites in the form of hormones, enzymes (such as protease; lipase; chitinase), antibiotics, and other compounds that are insecticidal. The purpose of this research was to study the effect of raw secondary metabolites from four entomopathogenic fungi isolates on B. tabaci mortality, the intensity of viral diseases, and the correlation between B. tabaci and the viral diseases.

\section{MATERIALS AND METHODS}

Propagation of the four entomopathogenic fungi

The four entomopathogenic fungi were $B$. bassiana B16, B. bassiana B10, M. anisopliae M16, and L. lecanii 
L16, collection of the Plant Protection Laboratory. Propagation of the entomopathogenic fungi was carried out using potato dextrose agar in a Petri dish and incubated for 7 days at room temperature (Yun et al. 2017).

\section{Making secondary metabolites}

The method for making secondary entomopathogenic fungi metabolites was carried out according to Kim et al. (2013), using potato dextrose broth. Medium PDB (200 g potato extract and $20 \mathrm{~g}$ sugar mixed into $1 \mathrm{~L}$ water) was prepared for sub-culture and activation of entomopathogenic fungi isolates. The cultured entomopathogenic fungi from the Petri dish was inoculated into an Erlenmeyer $(500 \mathrm{~mL})$ flask containing $(100 \mathrm{~mL})$ PDB medium, incubated at room temperature $28 \pm 2^{\circ} \mathrm{C}$, and shaker at $155 \mathrm{rpm}$ for one week.

\section{Preparation of secondary metabolite solutions for application}

Entomopathogenic fungi propagated using the PDB medium, the density of the conidia was calculated using a hemacytometer. According to Oliveira et al. (2018), conidia density was calculated by dripping $1 \mathrm{~mL}$ of entomopathogenic mushroom suspension which was propagated in the PDB medium onto the hemacytometer, conidia density was calculated with a 400 times magnification microscope. The density of conidia applied was $1 \times 10^{7}$ conidia/ $\mathrm{mL}$ for each isolate. The filtrate mess around $3000 \mathrm{rpm}$ for 5 minutes, then the filtrate was filtered again twice with Wattman filter paper No. 1 to then be applied by spraying (Rauf et al. 2018).

\section{Exploration and propagation of whitefly infestation}

Exploration is done by looking for pest imago in the agroecosystem around Banyumas. Propagation of whitefly infestation is carried out by breeding pests in chili plants that are covered by cage nets. Propagation of these pests is done until the pest population is sufficient for research activities.

\section{Experimental design}

The research design used for the Latin Square Design (RBSL) for in planta research and Randomized Group Design (RBD) for laboratory research. This study consisted of 5 treatments namely control and secondary metabolites of B. bassiana B16, B. bassiana B10, M. anisopliae M16, and L. lecanii L16. The conidia density used is $1 \times 10^{7}$ conidia / $\mathrm{mL}$. Each treatment in the in vitro mortality test was repeated 5 times, the in-planta test was repeated 5 times, and the qualitative test of chitinase activity was repeated 4 times.

\section{Large chili cultivation in the screen house}

Large chili cultivation is carried out in a screen house consisting of seedlings carried out by preparing a medium of manure on a tray. Chili seeds are sown on the surface of the planting medium and watered until the planting medium is damp. Planting is done with a planting medium in the form of a mixture of manure and soil. Mixed planting medium was loaded into polybags as much as 5 $\mathrm{kg} /$ polybag. Large chili seeds were transferred to polybags.
Weed sanitation is done manually.

\section{Making chitin agar medium}

Chitin agar medium was prepared by mixing $0.5 \%$ colloidal chitin, $\mathrm{K}_{2} \mathrm{HPO}_{4} 0.1 \mathrm{~g}, \mathrm{MgSO}_{4} .7 \mathrm{H}_{2} \mathrm{O} 0.01 \mathrm{~g}$, yeast extract $0.05 \mathrm{~g}$, peptone $0.1 \mathrm{~g}$, bacto tripton $0.1 \mathrm{~g}, \mathrm{NaCl}$, ( $\left.\mathrm{NH}_{4}\right)_{2} \mathrm{SO}_{4} 0.1 \mathrm{~g}$, and so that $1 \mathrm{~g}$ into an Erlenmeyer containing $100 \mathrm{~mL}$ of distilled water, the solution is then homogenized with a magnetic stirrer and heated until dissolved, then sterilized in an autoclave at $121^{\circ} \mathrm{C}$ for 15 minutes at a pressure of 2 atm (Rachmawaty 2009). The method of making chitin colloid (Haedar et al. 2017), which is as much as $20 \mathrm{~g}$ chitin from shrimp shell powder, plus $400 \mathrm{~mL}$ concentrated $\mathrm{HCl}$ and then tightly closed and left for 24 hours at $4^{\circ} \mathrm{C}$ (all treatment stages in cold temperatures). Next filtered using glass wool and filtrate plus $200 \mathrm{~mL}$ of cold water and the $\mathrm{pH}$ of the solution neutralized with $10 \mathrm{~N} \mathrm{NaOH}$ and spinning around 8000 rpm, temperature $4^{\circ} \mathrm{C}$ for 15 minutes. Pellet is washed with cold water and then mess around again. Pellet (colloidal chitin) is ready to use.

\section{Qualitative test of entomopathogenic fungal chitinase enzyme}

Chitinase enzyme qualitative test was performed by the method of Mubarik et al. (2010) modified, that is filter paper $(\mathrm{d}=5 \mathrm{~mm})$ soaked in a solution of secondary metabolites for 30 minutes and inoculated into chitin agar medium and incubated for 3 days. The clear zone is visualized by adding $0.1 \%$ congo red. The clear zone formed is measured based on the chitinolysis index formula (Rachmawaty 2009).

\section{Metabolite infectivity test secondary to whitefly (in-vitro)}

Large chili leaves are cut in a circle with a diameter of $3.5 \mathrm{~cm}$; immersed in a solution of secondary metabolites for 5 seconds, and glued upside down (the upper surface of the leaf attaches to the top of the Petri dish) (He et al. 2013). Whitefly as much as 10 adults were transferred into a Petri dish which already contained large chili leaf pieces (Abdel-Raheem and Al-Keridis 2017). The treatment consisted of secondary metabolites of four entomopathogenic fungi isolates $\left(1 \times 10^{7}\right.$ conidia $\left./ \mathrm{mL}\right)$ and control (without treatment). Each treatment was repeated 5 times. The total unit of the experiment was 25 Petri dishes so that the total imago B. tabaci needed was 250 . Mortality of whitefly infestation in modified Bioassays insecticide method by Yao et al. (2017), calculated by the formula Putra et al. (2013).

\section{Tests of metabolite infectivity secondary to disease variables due to virus carried by whitefly infestation in planta}

This activity was started by transferring large chili seeds aged 15 DAP in a $20 \times 25 \mathrm{~cm}$ polybag; the treatment consisted of secondary metabolites of four entomopathogenic and control fungi (without treatment) which were repeated 5 times; each trial unit has 3 units of plants, in total there are 75 large chili plants. After being placed, each plant is sprayed with a secondary metabolite 
solution according to the treatment in the morning before the B. tabaci imago is infested. The virus transmission procedure from a large chili inoculum uses imago $B$. tabaci. Imago is transferred using the mouth apparatus suction into the containment of a large chili plant that has been sick for 30 minutes to get the virus (Acquisition Access period). Imago B. tabaci has moved again to each experimental unit (Putra et al. 2013). Imago is transmitted to each experimental unit as many as 10 imagoes so that the total needed was 750 imagoes. Leaf samples from plants indicate symptoms of mosaic, chlorosis, yellowing, stunting, mottle, necrosis, leaf deformation, and leaf bunching. The disease intensity is calculated every 12 days by the formula (Gashaw et al. 2014):

$$
D I=\frac{\Sigma(n x v)}{N x z} \times 100 \%,
$$

Where; DI = disease intensity $(\%), \mathrm{n}=$ Number of plants in each category, $\mathrm{v}=$ Numerical values of symptoms category, $\mathrm{N}=$ Total number of plants, and $\mathrm{Z}=$ Maximum numerical value of symptom category.

Numerical value used to assess the disease intensity is by using a scale of 1-6 (Olawale et al. 2015) is: 1 . No visible symptoms; 2 . Mild mosaic/mottling/yellowing/mild necrosis on few leaves/branches of a plant (symptoms on less than $25 \%$ of the plant); symptom recovery; 3 . Moderate mosaic/puckering/mottling/yellowing/necrosis on many leaves/plants and vein clearing (symptoms cover $50 \%$ of the plant); 4. Severe mosaic/puckering/mottling/ yellowing/necrosis (symptoms on entire plant); 5. Severe mosaic/puckering/mottling/yellowing/necrosis and severe stunting (entire plant); and 6. Severe mosaic/puckering/ mottling/yellowing/necrosis and severe stunting (entire plant), and death of the infected plants.

\section{Data analysis}

Observation data were processed with Microsoft Excel 2010 (DSAASTAT), so that the F test results (significance level of 0.05) and further tests with HSD (significant level of 0.05 ).

\section{RESULTS AND DISCUSSION}

\section{Virulence of secondary metabolites of entomopathogenic fungi to adult $B$. tabaci}

Observation of insect death results in dead insects drying out like mummies. Insect tissue looks dry and blackish in color. The results showed (Table 1) that all secondary metabolites of entomopathogenic fungi were able to cause mortality against adult $B$. tabaci. The first observation showed that all secondary metabolites could cause low mortality. The second observation result showed that secondary metabolites of B. bassiana B16 (20.67\%) and L. lecanii L16 (24.89\%) were higher than $M$. anisopliae M16 (10.44\%) and B. bassiana B10 (10.22\%). The third and fourth observation result showed that $B$. bassiana B16 has highest mortality $(37.33 \%$; 45.28\%) followed by L. lecanii $(24.89 \% ; 35.56 \%)$ and M. anisopliae M16 (24.89\%; 35.33\%), then B. bassiana B10 (18.67\%; $28.33 \%$ ). The fifth and sixth observation result showed that secondary metabolites of $B$. bassiana B16 have highest mortality $(59.72 \% ; 67.38 \%)$ followed by B. bassiana B10 and $M$. anisopliae M16 (each by $50.00 \% ; 58.81 \%$ and $45,78 \%$; 56.22\%), and then L. lecanii L16 (44.72\%; $51.94 \%$ ). But, the secondary metabolites of $M$. anisopliae M16 and L. lecanii L16 did not significantly different. The last observation showed that secondary metabolites of $B$. bassiana B16, B, bassiana $\mathrm{B} 10$ and $M$. anisopliae M16 have highest mortality (each by $77.82 \% ; 71.47 \%$; and $66.67 \%$ ) followed by secondary metabolites of L. lecanii L16 (59.52\%).

This was found in all test insects, according to the explanation of Widariyanto et al. (2017). Each isolate has the ability to kill different test insects because of chitinase (Table 2). Internal factors that influence are isolate type (Soesanto 2017); propagule infectivity (Abdel-Raheem and Al-Keridis 2017); and the secondary metabolites it produces (Kim et al. 2013; Soesanto 2017). Analysis result of adult B. tabaci mortality due to secondary metabolites showed that secondary metabolites of B. bassiana B16 have a higher rate of increase in mortality (12.63\%) than other treatments. The lower rate of increase in mortality was shown sequentially by secondary metabolites of $B$. bassiana B10 (10.92\%), M. anisopliae M16 (10.12\%) and L. lecanii L16 (9.25\%). This shows the ability of the secondary metabolites of $B$. bassiana B16 to have high effectiveness on deadly test insects (B. tabaci pests; imago). Each secondary metabolites of entomopathogenic fungi have different time causing mortality. Internal factors that influence are isolate type (Soesanto 2017) and its secondary metabolites (Kim et al. 2013; Soesanto 2017). Internal factors that cause differences in the mortality rate of $B$. tabaci for each isolate are the ability to produce secondary metabolites in the form of the chitinase enzyme to support the infection process into the tissues (Suryadi et al. 2016).

Table 1. Virulence of secondary metabolites of four entomopathogenic fungi against adult Bemisia tabaci in mortality in-vitro test.

\begin{tabular}{|c|c|c|c|c|c|c|c|}
\hline \multirow{2}{*}{$\begin{array}{l}\text { Treatment } \\
\text { (secondary metabolites of) }\end{array}$} & \multicolumn{7}{|c|}{ Mortality of adult B. tabaci (\%) } \\
\hline & 12 & 24 & 36 & 48 & 60 & 72 & 84 \\
\hline B. bassiana $\mathrm{B} 16$ & $2 \mathrm{Fab}$ & $20.67 \mathrm{Fa}$ & $37.33 \mathrm{Ea}$ & $45.28 \mathrm{Da}$ & $59.72 \mathrm{Ca}$ & $67.38 \mathrm{Ba}$ & $77.82 \mathrm{Aa}$ \\
\hline B. bassiana $\mathrm{B} 10$ & $6 \mathrm{Ga}$ & $10.22 \mathrm{Fb}$ & $18.67 \mathrm{Ec}$ & $28.33 \mathrm{Dc}$ & $50.00 \mathrm{Cb}$ & $58.81 \mathrm{Bb}$ & $71.47 \mathrm{Aab}$ \\
\hline M. anisopliae M16 & $6 \mathrm{Fa}$ & $10.44 \mathrm{Fb}$ & $24.89 \mathrm{~Eb}$ & $35.33 \mathrm{Db}$ & $45.78 \mathrm{Cb}$ & $56.22 \mathrm{Bbc}$ & $66.67 \mathrm{Ab}$ \\
\hline L. lecanii L16 & $4 \mathrm{Fab}$ & $18.67 \mathrm{Ea}$ & $24.89 \mathrm{~Eb}$ & $35.56 \mathrm{Db}$ & $44.72 \mathrm{Cb}$ & $51.94 \mathrm{Bc}$ & $59.52 \mathrm{Ac}$ \\
\hline Control & $0 \mathrm{~Gb}$ & $0 \mathrm{Gc}$ & $0 \mathrm{Gd}$ & $0 \mathrm{Gd}$ & $0 \mathrm{Gc}$ & $0 \mathrm{Gd}$ & $0 \mathrm{Gd}$ \\
\hline
\end{tabular}

Note: number in a row which followed by same capital alphabetical means not different (HSD value 5,238); and number in a column which followed by same small alphabetical means not different (HSD value 6,711) 
According to Han et al. (2014), different pest death rates cause different Lethal Time (LT) values. LT is a value that represents the time required for insecticides, biopesticides, entomopathogenic fungi, and secondary metabolites to kill pests. According to Alavo et al. (2002), the term lethal time is also interpreted as 'killing time'. This term is related to the period required by active ingredients to kill test insects or target insects. LT50 value (Lethal Time 50), the time taken to kill insecticide $50 \%$ of the target pest population. According to Wang et al. (2004) and Han et al. (2014), the lower LT values showed more effective insecticides. As described by Han et al. (2014), $B$. bassiana B16 were most effective in causing mortality in B. tabaci imago base on its lethal time value.

\section{Chitinolytic index of secondary metabolites of four entomopathogenic fungi}

The qualitative test result showed (Table 2) the difference in the chitinolytic index for each secondary metabolites of entomopathogenic fungi. Secondary metabolites of $B$. bassiana B16 have the highest chitinolytic index by 3.5 then followed by secondary metabolites of L. lecanii L16 (2.00); B. bassiana B10 (1.68); and M. anisopliae M16 (0.73). This is in line with Ramanujam et al. (2011) and Mondal et al. (2016), that entomopathogenic fungi produce variant enzymatic activity of different enzymes. Chitinase enzyme is a secondary metabolite produced by entomopathogenic fungi and plays a role in increasing infectivity towards target insects (Suryadi et al. 2016). Chitinase enzyme degrades chitin and plays an important role in controlling harmful insect and fungal pathogens by catalyzing $\beta$ - $1 \rightarrow 4$-linkages in chitin $\left(\mathrm{C}_{8} \mathrm{H}_{13} \mathrm{O}_{5} \mathrm{~N}\right)_{n}$, a major polymer especially for building structural fungal cell walls (Hamid et al. 2013; Oyeleye and Normi 2018). Some entomopathogenic fungi tested indicated different chitinolytic index. The potency of entomopathogenic fungi depends on the capability of some enzymatic equipment such as chitinases and proteases (Mondal et al. 2016).

\section{Virus disease intensity on chili}

Virus disease intensity on chili in-plant test was observed according to the categories described by Arogundade et al. (2015). The in-plant test result showed
(Table 3) that all secondary metabolites of entomopathogenic fungi could decrease the disease intensity better than control from 24 to 33 DAP. But, on 37 to 41 DAP observation showed that the secondary metabolites of $B$. bassiana B16, B. bassiana B10 and L. lecanii L16 have lower disease intensity than $M$. anisopliae M16. Last observation result showed that the secondary metabolites of B. bassiana $\mathrm{B} 16$, B. bassiana $\mathrm{B} 10$ and L. lecanii $\mathrm{L} 16$ have the lowest disease intensity (each by $14.44,18.75$, and $20.03 \%$ or $79.98,74.00$, and $72.23 \%$ compared to control) then followed by M. anisopliae M16 (32.16\% or $55.41 \%$ compared to control). The intensity of the disease in tested plants was observed according to the categories described by Arogundade et al. (2015). All secondary metabolites of entomopathogenic fungi can reduce the intensity of viral diseases, each by $79.98 \%$ (B. bassiana B16); $74.00 \%$ (B. bassiana $\mathrm{B} 10$ ); $72.23 \%$ (L. lecanii L16); and 55.41\% ( $M$. anisopliae M16).

The ability to reduce the intensity of different viral diseases is due to the ability to increase the mortality of $B$. tabaci. According to Gerling et al. (1980) and Putra et al. (2013), management of viral diseases can be done by reducing the population of imago $B$. tabaci as a vector pest. The development of viruses in plant tissue directly interferes with plant growth. Symptoms of viral diseases that cause leaves to turn yellow, mosaic, curly and curled, according to the explanation Arogundade et al. (2015), can cause leaf function to decrease. As a result, photosynthesis is not optimum, so that plant growth is disrupted. The treatment of B. bassiana B16 and L. lecanii L16 showed the highest increase in plant height and number of leaves when compared with other treatments, such as B. bassiana B10 and M. anisopliae M16.

Table 2. Chitinolytic index of secondary metabolites of four entomopathogenic fungi

\begin{tabular}{ll}
\hline $\begin{array}{l}\text { Treatments } \\
\text { (Secondary metabolites of) }\end{array}$ & Chitinolytic index \\
\hline B. bassiana B16 & $3.50 \mathrm{a}$ \\
L. lecanii L16 & $2.00 \mathrm{ab}$ \\
B. bassiana B10 & $1.68 \mathrm{~b}$ \\
M. anisopliae M16 & $0.73 \mathrm{~b}$ \\
HSD Value & 1.7956 \\
\hline
\end{tabular}

Table 3. Virus disease intensity on chili in-planta test

\begin{tabular}{|c|c|c|c|c|c|}
\hline \multirow{2}{*}{$\begin{array}{l}\text { Treatments } \\
\text { (Secondary metabolites of) }\end{array}$} & \multicolumn{5}{|c|}{ Disease intensity (\%) } \\
\hline & 24 & 29 & 33 & 37 & 41 \\
\hline B. bassiana $\mathrm{B} 10$ & $6.93 \mathrm{Ba}$ & $7.10 \mathrm{Ba}$ & $9.41 \mathrm{ABa}$ & $10.37 \mathrm{ABa}$ & $18.75 \mathrm{Aa}$ \\
\hline B. bassiana $\mathrm{B} 16$ & $3.45 \mathrm{Aa}$ & $4.25 \mathrm{Aa}$ & $5.53 \mathrm{Aa}$ & $5.41 \mathrm{Aa}$ & $14.44 \mathrm{Aa}$ \\
\hline L. lecanii L16 & $3.38 \mathrm{Ba}$ & $3.97 \mathrm{Ba}$ & $6.56 \mathrm{Ba}$ & $6.62 \mathrm{Ba}$ & $20.03 \mathrm{Aa}$ \\
\hline M. anisopliae M16 & $6.95 \mathrm{Ba}$ & $13.14 \mathrm{Ba}$ & $15.76 \mathrm{Ba}$ & $28.03 \mathrm{Ab}$ & $32.16 \mathrm{Ab}$ \\
\hline Control & $30.71 \mathrm{Db}$ & $44.05 \mathrm{Cd}$ & $45.35 \mathrm{BCb}$ & $55.56 \mathrm{Bc}$ & $72.12 \mathrm{Ac}$ \\
\hline
\end{tabular}

Note: number in a row which followed by same Capital alphabetical means not different (HSD value 11,022); and number in a column which followed by same small alphabetical means not different (HSD value 11,022) 
Table 4. Secondary metabolites of entomopathogenic fungi effect on chili in-plant test which infested by adult Bemisia tabaci

\begin{tabular}{lcc}
\hline $\begin{array}{c}\text { Treatments } \\
\text { (Secondary metabolites } \\
\text { of })\end{array}$ & $\begin{array}{c}\text { Increasing } \\
\text { plant height } \\
(\boldsymbol{\%})\end{array}$ & $\begin{array}{c}\text { Increasing total } \\
\text { leaf per plant } \\
(\boldsymbol{\%})\end{array}$ \\
\hline B. bassiana B16 & 173.35 & 69.66 \\
L. lecanii L16 & 172.56 & 91.70 \\
B. bassiana B10 & 90.82 & 54.55 \\
M. anisopliae M16 & 105.49 & 49.20 \\
Control & - & - \\
\hline
\end{tabular}

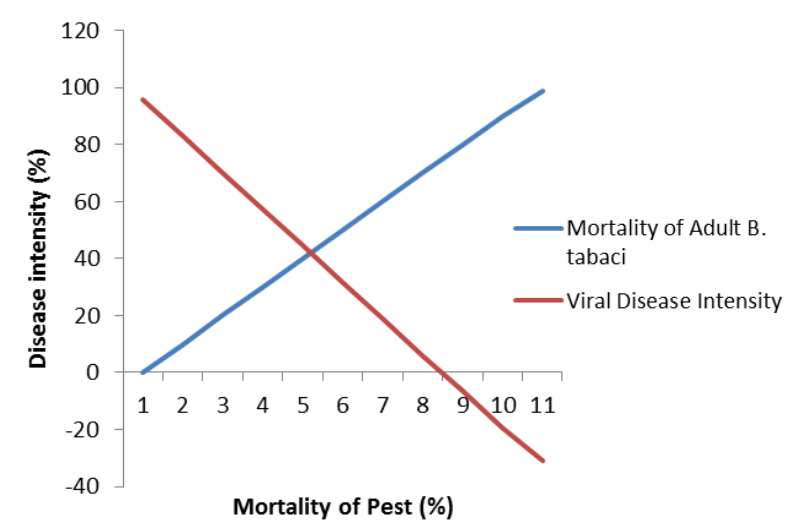

Figure 1. Correlation between adult whitefly mortality and virus disease intensity

\section{Plant growth}

The development of viruses in plant tissue interferes with plant growth (Arogundade et al. 2015). The result of in-planta test showed (Table 4) that the secondary metabolites of entomopathogenic fungi could be increasing plant height better than control plant by $173.35 \%$ (B. bassiana B16); $172.56 \%$ (L. lecanii L16); 105.49\% (M. anisopliae M16); and 90.82\% (B. bassiana B10). Also, secondary metabolites of entomopathogenic fungi could be increasing total leaf per plant by $91.70 \%$ (L. lecanii L16); $69.66 \%$ (B. bassiana B16); 54.55\% (B. bassiana B10); and $49.20 \%$ (M. anisopliae M16). The treatment of B. bassiana B16 is thought to be able to influence growth (plant height and number of leaves) because it causes the highest pest mortality so that the potential for the virus is reduced. According to Yin et al. (2003), the sub-phase of plant growth and development can be divided into three growth stadia, namely rapid growth in the beginning (vegetative); linear growth; and the saturation phase for aging or fruit ripening. According to El-bassiony et al. (2010), increasing vegetative growth of plants was carried out to obtain plants with good vigor. The effort to keep plants from becoming infected with disease is also a step to maintain vegetative growth of plants. Therefore, the treatment of secondary metabolites of entomopathogenic fungi can increase vigor in the form of plant height and a higher number of leaves because it can reduce the intensity of disease.
Table 5. Pearson value and regression analysis between mortality and disease intensity

\begin{tabular}{lcc}
\hline $\begin{array}{c}\text { Treatments (Secondary } \\
\text { metabolites of) }\end{array}$ & $\begin{array}{c}\text { Pest mortality } \\
(\mathbf{\%})\end{array}$ & $\begin{array}{c}\text { Virus disease } \\
\text { intensity }(\boldsymbol{\%})\end{array}$ \\
\hline Control & 0 & 72.12 \\
M. anisopliae M16 & 66.7 & 32.16 \\
L. lecanii L16 & 59.5 & 20.03 \\
B. bassiana B10 & 71.5 & 18.75 \\
B. bassiana B16 & 77.8 & 14.44 \\
Pearson $=$ & -0.965319379 & \\
& $\mathrm{Y}=95.642-1.287 \mathrm{X}$ \\
\hline
\end{tabular}

\section{Relationship between pest mortality and intensity of disease}

Calculation of the correlation value and regression between pest mortality and disease intensity can be seen in Table 5 .

The Pearson analysis result showed a correlation between pest mortality (adult whitefly) and disease intensity (virus vector) by -0.9653 . Also, the regression analysis resulted in $\mathrm{Y}=95.642-1.278 \mathrm{X}$.

Graph of the relationship between pest mortality and disease intensity (Figure 1), it is known that the inverse nature between pest mortality and pest intensity is proven (negative correlation value results). Based on the results of calculations with the Pearson formula in Table 5, it is known the value of correlation between pest mortality and disease intensity is (negative) -0.965 . This value can be categorized high or very closely with the negative nature which means the opposite. This is in accordance with the explanation of Gerling et al. (1980), the population of $B$. tabaci whitefly infestation greatly influences the intensity of disease in an agroecosystem, causing significant loss of yield if not managed properly. Regression calculations are performed to find out further relationships between the two variables. Based on the graph of the relationship between pest mortality and disease intensity, it is known that the inverse nature between pest mortality and pest intensity is proven. That is if there is an increase in mortality in $B$. tabaci will cause a decrease in the intensity of the disease due to viruses carried by vector pests. According to Horowitz et al. (2011) increasing the vulnerability of active ingredients to control B. tabaci populations can reduce the potential of viruses that can infect plants.

\section{REFERENCES}

Abdel-Raheem MA, Al-Keridis LA. 2017. Virulence of three entomopathogenic fungi against whitefly, Bemisia tabaci (Gennadius) (Hemiptera: Aleyrodidae) in tomato crop. J Entomol 14 (4): 155-159. DOI: $10.3923 /$ je.2017.155.159.

Alavo TBC, Sermann H, Bochow H. 2002. Virulence of strains of the entomopathogenic fungus Verticillium lecanii to phids: strain improvement. Archives of Phytopathology and Plant Protection 34 (6): 379-398. DOI: 10.1080/716061669.

Arogundade O, Balogun OS, Akinyemi SOS, Kumar PL. 2015. Surveys of virus diseases on pepper (Capsicum spp.) in South-west Nigeria. Afr J Biotechnol 14 (48): 3198-3205. DOI: 10.5897/AJB2015.14803. 
De Barro PJ, Liu S-S, Boykin LM, Dinsdale AB. 2011. Bemisia tabaci : A statement of species status. Annual Review of Entomology 56 (1): 1 19. DOI: 10.1146/annurev-ento-112408-085504.

El-bassiony AM, Fawzy ZF, Abd El-Samad EH, Riad GS. 2010. Growth, yield and fruit quality of sweet pepper plants (Capsicum anпиит L.) as affected by potassium fertilization. J Amer Sci 6 (12): 722-730.

Fernandes EG, Valério HM, Feltrin T, Sand STV. 2012. Variability in the production of extracellular enzymes by entomopathogenic fungi grown on different substrates. Brazilian J Microbiol 43: 827-833.

Gashaw G, Alemu T, Tesfaye K. 2014. Evaluation of disease incidence and severity and yield loss of finger millet varieties and mycelial growth inhibition of Pyricularia grisea isolates using biological antagonists and fungicides in vitro condition. J Appl Biosci 73: 58835901.

Gerling D, Motro U, Horowitz R. 1980. Dynamics of Bemisia tabaci (Gennadius) (Homoptera: Aleyrodidae) attacking cotton in the coastal plain of Israel. Bull Entomol Res 70 (2): 213-219. DOI: 10.1017/S000748530000746X.

Haedar N, Natsir H, Fahruddin, Aryanti W. 2017. Production and characterization of chitinase enzymes from chitinolytic bacteria from Anadara granosa shellfish. J Ilm Alam Ling 8 (15): 14-21.

Hamid R, Khan MA, Ahmad M, Ahmad MM, Abdin MZ, Musarrat J, Saleem Javed S. 2013. Chitinases: An update. J Pharm Bioallied Sci. 5(1): 21-29. DOI: 10.4103/0975-7406.106559.

Han JH, Jin BR, Kim JJ, Lee SY. 2014. Virulence of entomopathogenic fungi Metarhizium anisopliae and Paecilomyces fumosoroseus for the microbial control of Spodoptera exigua. Mycobiology 42 (4): 385 390. DOI: 10.5941/MYCO.2014.42.4.385.

He Y, Zhao J, Zheng Y, Weng Q, Biondi A, Desneux N, Wu K. 2013. Assessment of potential sublethal effects of various insecticides on key biological traits of the tobacco whitefly, Bemisia tabaci. Intl J Biol Sci 9 (3): 246-255. DOI: 10.7150/ijbs.5762.

Horowitz AR, Antignus Y, Gerling D. 2011. Management of Bemisia tabaci Whiteflies: The Whitefly, Bemisia tabaci (Homoptera: Aleyrodidae) Interaction with Geminivrus-Infected Host Plants. (W M. O. Thompson, Ed.). National Agricultural Research Institute, USA. Retrieved from http://www.springer.com/10.1007/978-94-0071524-0.

Keyhani NO. 2018. Lipid biology in fungal stress and virulence: Entomopathogenic fungi. Fungal Biology 122 (6): 420-429. DOI 10.1016/j.funbio.2017.07.003.

Kim JJ, Jeong G, Han JH, Lee S. 2013. Biological control of aphid using fungal culture and culture filtrates of Beauveria bassiana. Mycobiology 41 (4): 221-224. DOI: 10.5941/MYCO.2013.41.4.221.

Legg JP, Shirima R, Tajebe LS, Guastella D, Boniface S, Jeremiah S, Nsami E, Chikoti P, Rapisarda C. 2014. Biology and management of Bemisia whitefly vectors of cassava virus pandemics in Africa. Pest Manag Sci 70 (10): 1446-1453. DOI: 10.1002/ps.3793.

Liu CP, Lin PW. 2013. Titanium dioxide nanoparticles as UV protectants for enhancing the survival of conidia of the entomopathogenic fungus Intl J Innov Biol Res 2 (1): 21-29.

Macfadyen S, Paull C, Boykin LM, De Barro P, Maruthi MN, Otim M, Kelyebi A, Vassao DG, Sseruwangi P, Tay WT, Delatte H, Seguni Z, Colvin J, Omongo CA. 2018. Cassava whitefly, Bemisia tabaci (Gennadius) (Hemiptera: Aleyrodidae) in East African farming landscapes: a review of the factors determining abundance. Bull Entomol Res 108 (5): 565-582. DOI: 10.1017/S0007485318000032.

Mascarin GM, Kobori NN, Quintela ED, Delalibera I. 2013. The virulence of entomopathogenic fungi against Bemisia tabaci biotype B (Hemiptera: Aleyrodidae) and their conidial production using solid substrate fermentation. Biol Control 66 (3): 209-218. DOI: 10.1016/j.biocontrol.2013.05.001.

Mondal S, Baksi S, Koris A, Vatai G. 2016. Journey of enzymes in entomopathogenic fungi. Pacific Sci Rev A: Nat Sci Eng 18 (2); $85-$ 99. DOI: 10.1016/j.psra.2016.10.001.

Moreno-Delafuente A, Garzo E, Moreno A, Fereres A. 2013. A plant virus manipulates the behavior of its whitefly vector to enhance its transmission efficiency and spread. PLoS ONE 8 (4): e61543. DOI: 10.1371/journal.pone.0061543.
Mubarik NR, Mahagiani I, Anindyaputri A, Santoso S, Rusmana I. 2010. Chitinolytic bacteria isolated from chili rhizosphere: Chitinase characterization and its application as biocontrol for whitefly (Bemisia tabaci Genn.). Amer J Agric Biol Sci 5 (4): 430-435.

Mustafa U, Kaur G. 2008. UV-B radiation and temperature stress causes variable growth response in Metarhizium anisopliae and Beauveria bassiana isolates. Internet J Microbiol 7 (1): 1-8.

Navas-Castillo J, Fiallo-Olivé E, Sánchez-Campos S. 2011. Emerging virus diseases transmitted by whiteflies. Ann Rev Phytopathol 49 (1): 219-248. DOI: 10.1146/annurev-phyto-072910-095235.

Olawale A, Samuel BO, Solomon ASO, Kumar PL. 2015. Surveys of virus diseases on pepper (Capsicum spp.) in south-west Nigeria. Afr J Biotechnol 14 (48): 3198-3205. DOI: 10.5897/AJB2015.14803.

Oliveira AS, Braga GUL, Rangel DEN. 2018. Metarhizium robertsii illuminated during mycelial growth produces conidia with increased germination speed and virulence. Fungal Biol 122 (6): 555-562. DOI: 10.1016/j.funbio.2017.12.009.

Oyeleye A, Normi YM. 2018. Chitinase: diversity, limitations, and trends in engineering for suitable applications. Biosci Rep 38 (4): BSR2018032300. DOI: 10.1042/BSR20180323.

Putra G, Hadiastono T, Afandhi A, Prayogo Y. 2013. Pathogenicity of the entomopathogenic fungus Lecanicillium lecanii (Deuteromycotina: Hyphomycetes) against Bemisia tabaci (G.) as a vector of cowpea mild mottle virus (CMMV) in soybean plants. Jurnal Hama dan Penyakit Tumbuhan 1 (1): 27-39.

Rachmawaty. 2009. The comparation chitinase enzyme of Beauveria bassiana local strain South Sulawesi to mortality Spodoptera litura. Bionature 10 (2): 60-64.

Ramanujam B, Balachander M, Roopa G, Rangeshwaran R, Karmakar P. 2011. Chitinase activity and virulence of different isolates of Beauveria bassiana, Metarhizium anisopliae and Lecanicillium spp. J Biol Control 25 (3): 223-228.

Rauf S, Ali Y, Hussain S, Ullah F, Hayat A. 2018. Design of a novel filter paper based construct for rapid analysis of acetone. PLOS ONE 13 (7): e0199978. DOI: 10.1371/journal.pone.0199978.

Rodríguez E, Téllez MM, Janssen D. 2019. Whitefly control strategies against Tomato Leaf Curl New Delhi Virus in greenhouse zucchini. Intl J Environ Res Public Health 16 (15): 2673. DOI: 10.3390/ijerph16152673.

Soesanto L. 2017. Introduction to Biological Pesticides: Addendum to Secondary Metabolites of Biological Agents. PT Raja Graffindo Persada, Jakarta. [Indonesian].

Supriadi RD, Susila AD, Sulistyono E. 2018. Penetapan kebutuhan air tanaman aabai merah (Capsicum annuum L.) dan cabai rawit (Capsicum frutescens L.). Jurnal Hortikultura Indonesia 9 (1): 38-46. DOI: 10.29244/jhi.9.1.38-46. [Indonesian]

Suryadi Y, Priyatno TP, Samudra IM, Susilowati DN, Lawati N, Kustaman E. 2016. Pemurnian parsial dan karakterisasi kitinase asal jamur entomopatogen Beauveria bassiana isolat BB200109. Jurnal AgroBiogen 9 (2): 77. DOI: 10.21082/jbio.v9n2.2013.p77-84.

Wang L, Huang J, You M, Liu B. 2004. Time-dose-mortality modelling and virulence indices for six strains of Lecanicillium lecanii against sweet potato whitefly, Bemisia tabaci (Gennadius). J Appl Entomol 128 (7): 494-500. DOI: 10.1111/j.1439-0418.2004.00879.

Widariyanto R, Pinem MI, Zahara F. 2017. Pathogenicity of some entomophatogen's fungus (Lecanicillium lecanii, Metarhizium anisopliae, and Beauveria bassiana) to Aphis glycines on Soybean. Jurnal Agroekoteknologi 5 (2): 8-16.

Yao F-L, Zheng Y, Huang X-Y, Ding X-L, Zhao J-W, Desneux N, He YX, Weng Q-Y. 2017. Dynamics of Bemisia tabaci biotypes and insecticide resistance in Fujian province in China during 2005-2014. Sci Rep 7 (1): 40803 . DOI: 10.1038/srep40803.

Yin X, Gourdriaan J, Lantinga EA, Vos J, Spiertz HJ. 2003. A flexible sigmoid function of determinate growth. Ann Bot 91 (3): 361-371. DOI: $10.1093 / \mathrm{aob} / \mathrm{mcg} 029$.

Yun H-G, Kim D-J, Gwak W-S, Shin T-Y, Woo S-D. 2017. Entomopathogenic fungi as dual control agents against both the pest Myzus persicae and phytopathogen Botrytis cinerea. Mycobiology 45 (3): 192-198. DOI: 10.5941/MYCO.2017.45.3.192. 